\title{
Model Regresi Poisson Tergeneralisasi untuk Anak Gizi Buruk di Sulawesi Utara
}

\author{
Faranika Deysi Glarita Maneking ${ }^{1)}$, Deiby Tineke Salaki ${ }^{1)}$, Djoni Hatidja ${ }^{1)}$ \\ ${ }^{1)}$ Program Studi Matematika, Fakultas Matematika dan Ilmu Pengetahuan Alam \\ Universitas Sam Ratulangi, Indonesia \\ deysimaneking@gmail.com; deibyts.mat@unsrat.ac.id ; djonihatidja@gmail.com
}

(Article History: Received 11-07-2020; Accepted 28-10-2020; Published 31-10-2020)

\begin{abstract}
ABSTRAK
Salah satu masalah kesehatan yang sering terjadi di Indonesia adalah gizi buruk. Seorang anak yang mengalami gizi buruk akan rentan terhadap berbagai penyakit karena sistem kekebalan tubuhnya mudah terinfeksi virus. Jumlah kasus anak gizi buruk merupakan data diskrit yang dapat dimodelkan dengan regresi poisson. Penelitian ini bertujuan untuk menentukan model regresi poisson tergeneralisasi dalam mengatasi overdispersi pada model regresi poisson dari jumlah kasus gizi buruk dan menentukan faktor-faktor yang mempengaruhi jumlah kasus gizi buruk di Sulawesi Utara tahun 2018. Data yang digunakan berupa jumlah kasus gizi buruk sebagai variabel respon dan sejumlah variabel prediktor dengan unit pengamatannya adalah kota dan kabupaten di Sulawesi Utara. Hasil penelitian menunjukkan bahwa variabel yang mempengaruhi jumlah anak gizi buruk di Sulawesi Utara adalah persentase bayi dengan berat badan lahir rendah (BBLR) dan variabel yang tidak berpengaruh signifikan adalah jumlah posyandu, persentase keluarga yang memiliki sanitasi layak pakai, jumlah penduduk miskin, persentase bayi yang menggunakan ASI ekslusif dengan model regresi poisson tergeneralisasi $\widehat{\boldsymbol{Y}}=\exp \left(0,892+0,019 X_{2}\right)$.
\end{abstract}

Kata kunci: Keluarga eksponensial; multikolinearitas; overdispersi; Sulawesi Utara

\section{Generalized Poisson Regression Model For Malnourished Children in North Sulawesi}

\begin{abstract}
One of the health problems that often occurs in Indonesia is malnutrition. A child who is suffering from malnutrition will be vulnerable to various diseases because his immune system is easily infected by a virus. The number of cases of malnutrition children is discrete data that can be modeled by Poisson regression. This study aimed to determine the Generalized Poisson Regression (GPR) model for handling the overdispersion occurred in the Poisson regression model of the number of malnutrished children case and also to determine the factors that influence the number of malnutrished children case in North Sulawesi in 2018. This study utilizes the number of cases of malnutrition as a response variable and a number of predictor variables with the observation unit was cities and districts in North Sulawesi. The results of this study indicate that the variables that significantly affect the number of malnourished children in North Sulawesi include the percentage of child with low weight birth (LWB) and variables that have no significant effect are the number of posyandu, the percentage of families who have decent sanitation, the number of poor people, the percentage of babies who use exclusive breast milk with the generalized poisson regression model $\widehat{\boldsymbol{Y}}=\exp \left(0,892+0,019 X_{2}\right)$.
\end{abstract}

Keywords: Exponential family; multicolinearity; overdispersion; North Sulawesi

\section{PENDAHULUAN}

Gizi buruk (GB) adalah status gizi menurut berat badan $(\mathrm{BB})$ dan tinggi badan (TB) dengan Z-score $=-3$ dan atau tanda-tanda klinis (Maramus, kwashiorkor, dan maramus kwashiorkor) (DINKES Provinsi Sulawesi
Utara, 2017). GB merupakan salah satu masalah kesehatan yang kerap terjadi di kalangan masyarakat Indonesia dan sebagian besar negara berkembang lainnya. Status GB menjadi masalah yang serius karena merupakan salah satu indikator tingkat 
kesejahteraan masyarakat (BPS Provinsi Sulawesi Utara, 2019). Menurut BPS Provinsi Sulawesi Utara (2019), kasus GB di Sulawesi Utara (Sulut) tahun 2018 tercatat ada 28 kasus dan yang tertinggi ada di kota Manado yaitu ada sebanyak 6 kasus. Jumlah ini mengalami kenaikan dari tahun 2017 yaitu sebanyak 25 kasus dan tahun 2016 sebanyak 24. GB di Sulut memang tergolong rendah dibandingkan provinsi lain di Indonesia namun apabila gizi buruk dan gizi kurang terus terjadi dapat menjadi faktor penghambat dalam pembagunan nasional. Pada kondisi GB, penurunan produktivitas perorangan diperkirakan lebih dari 10 persen dari potensi pendapatan seumur hidup dan secara agregat menyebabkan kehilangan PDB antara 2-3 persen (BAPPENAS, 2006). Mengetahui hal ini pemerintah dan dinas terkait terus melakukan berbagai program sebagai upaya untuk menurunkan prevelensi GB melalui pemberian makanan pendamping ASI dan suplementasi zat gizi, upaya pemberdayaan masyarakat untuk memperbaiki pola asuh balita yang meliputi penerapan inisiasi menyusui dini, memberi ASI secara eksklusif sampai bayi mencapai usia 6 bulan" (DINKES Provinsi Sulawesi Utara, 2017). Perpres No. 42 Tahun 2013 tentang " Gerakan Nasional Percepatan Perbaikan Gizi meliputi : Sanitasi berbasis lingkungan, memberikan anggaran disetiap desa, dan pembagunan infrastruktur air minum dan sanitasi untuk kualitas hidup manusia. Melalui program-program ini diharapkan dapat menurunkan berbagai faktor yang menyebabkan pertambahan GB.

Penelitian terkait GB di Sulut sudah banyak dilakukan dengan berbagai metode, seperti penelitian yang dilakukan oleh Hosang et al. (2017), mengungkap perubahan status gizi anak balita kurang di kota Manado dari hubungannya dengan pemberian makan tambahan menggunakan analisis retrospektif. Kumayas et al. (2019) mengkaji hubungan status imunisasi dan penyakit infeksi dengan status gizi balita di desa Tateli menggunakan metode cross-sectional. Meski demikian sepanjang penelusuran pustaka oleh penulis, penggunaan metode poisson tergeneralisasi belum digunakan. Oleh karena itu, pada penelitian ini akan dimodelkan jumlah kasus anak gizi buruk di Provinsi Sulut tahun 2018 dengan metode regresi poisson, ketika terjadi pelanggaran equidispersi pada variabel respon yang diindikasi dengan lebih besarnya nilai ragam dari pada nilai rataan maka metode poisson tidak dapat dilanjutkan dan dilanjutkan dengan metode poisson tergeneralisasi. Beberapa Faktor yang digunakan dalam penelitian ini adalah jumlah posyandu, jumlah bayi yang lahir dengan berat badan lahir rendah (BBLR), persentase keluarga yang memiliki sanitasi layak pakai, jumlah penduduk miskin, persentase bayi yang mendapat ASI eksklusif.

\section{METODE PENELITIAN}

\section{Data}

Data yang digunakan pada penelitian ini adalah data sekunder yang diperoleh dari Badan Pusat Statistika (BPS) Provinsi Sulawesi Utara dan Dinas Kesehatan Provinsi Sulawesi Utara. Pada penelitian ini menggunakan data kabupaten/kota di provinsi Sulawesi Utara tahun 2018 yang terdiri dari 15 kabupaten/kota. Terdapat 4 kota di Sulawesi Utara yaitu: Bitung, Kotamobagu, Manado, Tomohon. Sebelas kabupatennya adalah Bolaang Mangondow Timur (Boltim), Bolaang Mangondow Selatan (Bolsel), Bolaang Mangondow Utara (Bolmut), Bolaang Mangondow (Bolmong), Kapulauan Sangihe (Sangihe), Kepulauan Talaud (Talaud), Minahasa, Minahasa Selatan (Minsel), Minahasa Tenggara (Mitra), Minahasa Utara (Minut), Kepulauan Siau Tagulandang Biaro (Sitaro).

Variabel respon dalam penelitian ini adalah jumlah anak gizi buruk Sulawesi Utara $(Y)$ dan variabel prediktor dalam penelitian ini adalah jumlah posyandu $\left(X_{1}\right)$, jumlah berat bayi lahir rendah $\left(X_{2}\right)$, persentase keluarga yang memiliki sanitasi layak pakai $\left(X_{3}\right)$, jumlah penduduk miskin (ribu) $\left(X_{4}\right)$, persentase bayi yang menggunakan ASI ekslusif $\left(X_{5}\right)$.

\section{Metode Analisis}

Analisis data dilakukan dengan menggunakan perangkat lunak RStudio. Tahapan penelitian yang dilakukan meliputi:

1. Menginput data

2. Mendeskripsikan data jumlah gizi buruk.

3. Uji goodness of fit data jumlah gizi buruk

4. Memeriksa hubungan antara variabel prediktor (multikoleniaritas).

5. Menentukan model regresi poisson 
6. Melakukan pengujian parameter model regresi poisson dengan uji parsial

7. Identifikasi overdispersi

8. Menentukan model regresi poisson tergeneralisasi jika terjadi overdispersi

9. Melakukan pengujian parameter model regresi poisson tergeneralisasi dengan uji parsial

10.Menarik kesimpulan

\section{HASIL DAN PEMBAHASAN}

\section{Deskripsi Data}

Gambar 1, menunjukkan jumlah gizi buruk di 15 kabupaten/kota di Sulawesi Utara tahun 2018. Data tersebut jumlah penderita gizi buruk anak-anak dengan rentang usia 0 59 bulan. Kasus terbanyak terjadi di kota Manado dan yang paling sedikit yaitu nol terjadi di kabupaten/kota Bolmong, Sitaro, Tomohon.

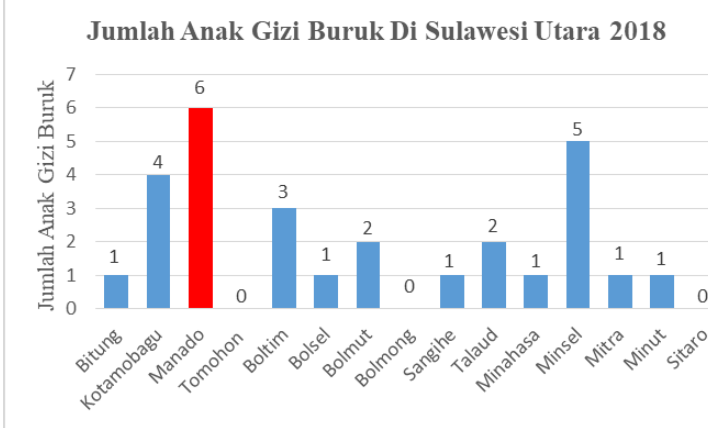

Gambar 1. Grafik Jumlah Gizi Buruk di Sulawesi Utara 2018

Uji goodness of fit atau kebaikan suai digunakan untuk menguji bagaimana sebaran teoritik dari suatu populasi tertentu. Karena didasarkan pada besaran yang menyebar khikuadrat maka uji ini disebut juga uji khikuadrat (Walpole, 1995). Besaran tersebut diformulasikan sebagai berikut

$$
\chi^{2}=\sum_{i=1}^{k} \frac{\left(o_{i}-e_{i}\right)^{2}}{e_{i}}
$$

dengan $o_{i}$ merupakan frekuensi teramati dan $e_{i}$ adalah frekuensi harapan bagi sel ke- $i$.

$e_{i}=\frac{\text { Jumlah baris } \times \text { Jumlah kolom }}{\text { Jumlah data }}$, Hipotesisnya yaitu:

$H_{0}$ : Data menyebar poisson

$H_{1}$ : Data tidak menyebar poisson

Hipotesis $H_{0}$ ditolak jika $\chi^{2}>$ $\chi_{(\text {db(derajat bebas }) ; \alpha)}^{2}$ atau $p$-value $<\alpha$ yang artinya data tersebut tidak menyebar secara poisson.
Hasil pengujian Goodness of Fit menunjukkan bahwa $\chi^{2}=6,103$ yang lebih kecil dari nilai tabel $\chi_{(14 ; 0,05)}^{2}=23,685$. Selain itu, pada taraf signifikan 0,05 hasil $p$ value $=0,296$. Dengan demikian dapat disimpulkan bahwa data jumlah gizi buruk menyebar poisson.

\section{Uji Multikolinieritas}

Multikolinieritas merupakan adanya korelasi yang tinggi antar variabel prediktor dalam model. Pendeteksian kasus multikolinieritas dapat dilihat melalui nilai VIF (Varians Inflation Factor) yang jika lebih dari 10 menunjukkan adanya multikolinieritas. Nilai VIF dinyatakan dengan rumus:

$V I F_{j}=\frac{1}{1-R_{j}^{2}}$

$R_{j}^{2}=$ Koefisien determinasi antara $X_{j}$ dengan variabel prediktor lainnya (Hocking, 1996).

Tabel 1. Nilai VIF Masing-Masing Variabel

\begin{tabular}{ccc}
\hline Variabel & & Nilai VIF \\
\hline & $X_{1}$ & 6,757 \\
& $X_{2}$ & 1,422 \\
$X_{3}$ & 1,353 \\
$X_{4}$ & 5,880 \\
$X_{5}$ & 1,273 \\
\hline
\end{tabular}

Data yang diperoleh dianalisis dengan mengunakan perangkat lunak statistik sesuai dengan rumus pada persamaan 1 yang hasilnya terlihat pada Tabel 1. Semua variabel prediktor memiliki nilai VIF kurang dari 10 dan dapat disimpulkan bahwa tidak terjadi multikolinieritas. Dengan demikian kelima variabel tersebut dapat digunakan untuk memodelkan jumlah anak gizi buruk di Sulawesi Utara (Tabel 1).

\section{Model Regresi Poisson}

Regersi poisson termasuk dalam Generalized Linear Models GLM karena variabel respon menyebar menurut keluarga eksponsial. Regresi poisson mengasumsikan tidak ada multikoleniaritas antar variabel prediktor dan mengasumsikan ekuidispersi (Agresti, 2006).

Fungsi penghubung yang digunakan dalam regresi Poisson adalah fungsi penghubung log, karena rata-rata dari variabel responnya akan berbentuk fungsi eksponensial dan menjamin bahwa nilai variabel yang 
ditaksir variabel responnya akan bernilai nonnegatif. :

$g\left(\theta_{i}\right)=\ln \left(\theta_{i}\right)=\boldsymbol{x}_{i}^{T} \beta$

$\theta_{i}=\exp \left(\boldsymbol{x}_{i}^{T} \beta\right)$

Tabel 2. Estimasi Parameter Model Regresi Poisson

\begin{tabular}{|c|c|c|c|}
\hline Parameter & Estimasi & Galat Baku & $\operatorname{Pr}(>|z|)$ \\
\hline Intercept & 2,704 & 1,614 & 0,094 \\
\hline$\beta_{1}$ & $-0,0005$ & 0,006 & 0,935 \\
\hline$\beta_{2}$ & 0,016 & 0,009 & 0,075 \\
\hline$\beta_{3}$ & $-0,024$ & 0,022 & 0,273 \\
\hline$\beta_{4}$ & 0,029 & 0,074 & 0,698 \\
\hline$\beta_{5}$ & $-0,041$ & 0,027 & 0,128 \\
\hline
\end{tabular}

Hasil estimasi parameter model terdapat pada Tabel 2. Berdasarkan hasil tersebut, model regresi poisson untuk rataan jumlah gizi buruk $(\widehat{\boldsymbol{\theta}})$ di Sulawesi Utara adalah sebagai berikut:

$\widehat{\boldsymbol{\theta}}=\exp \left(2,704-0,0005 X_{1}+0,016 X_{2}-\right.$

$\left.0,024 X_{3}+0,029 X_{4}-0,041 X_{5}\right)$

\section{Pengujian Signifikansi Parameter Model}

Uji parsial digunakan untuk menguji setiap $\beta_{j}$ secara individu memiliki pengaruh yang signifikan terhadap variabel respon (Dobson \& Barnett, 2018; Hocking, 1996). Hipotesisnya yauti:

$H_{0}: \beta_{j}=0$ dan $H_{1}: \beta_{j} \neq 0 ; j=1,2, \ldots p$ Statistik Uji

$W=\left(\frac{\beta_{j}}{S E \beta_{j}}\right)^{2}$

$\beta_{j}$ merupakan nilai dugaan untuk parameter $\beta_{j}$ dan $S E \beta_{j}$ merupakan Dugaan galat baku untuk koefisien $\beta_{j}$. Nilai wald mengikuti distribusi chi-square sehingga dibandingkan dengan tabel chi-square $X^{2}(d b=1 ; \alpha)$. Kriteria uji untuk pengambilan keputusan dengan taraf nyata $(\alpha)$ adalah tolak $H_{0}$ jika nilai $W_{j}>$ $X^{2}{ }_{(d b=1 ; \alpha)}$ atau dapat dilihat berdasarkan $p-$ value $<\alpha$, dimana nilai $\alpha=0.05$.

Hasil uji wald model poisson sebagaimana ditampilkan pada Tabel 3 . menunjukkan masing-masing variabel memiliki nilai wald yang kurang dari nilai tabel $\quad \mathrm{X}_{(1 ; 0,05)}=3,841$. Hal ini mengindikasikan bahwa $H_{0}$ diterima, yang artinya pada $\alpha=0,05$ semua variabel prediktor tidak berpengaruh secara signifikan pada jumlah gizi buruk di Propinsi Sulawesi Utara (Y). Tabel 3, merupakan uji wald yang dihitung menggunkan rumus pada persamaan 4.

Tabel 3. Pengujian Wald untuk Regresi Poisson

\begin{tabular}{ccc}
\hline Variabel & \multicolumn{2}{c}{ Wald } \\
\hline$X_{1}$ & \multicolumn{2}{c}{0,007} \\
$X_{2}$ & \multicolumn{2}{c}{3,171} \\
$X_{3}$ & \multicolumn{2}{c}{1,204} \\
$X_{4}$ & \multicolumn{2}{c}{0,150} \\
$X_{5}$ & \multicolumn{2}{c}{2,312} \\
\hline Var. Respon & Rata-rata & Ragam \\
\hline Y & 1,86667 & 3,40952 \\
\hline
\end{tabular}

Hasil dari pengujian ini menunjukkan bahwa model regresi poisson tidak berhasil mengungkap hubungan antara keenam variabel bebas dengan variabel respon. Jika dilihat dari peubah respon, nilai ragamnya adalah 3,409 lebih besar dari nilai rata-ratanya yaitu 1,866 yang mengindikasikan adanya pelanggaran equidispersi sehingga model regresi poisson tidak dapat digunakan (Tabel $3)$.

Pengujian overdispersi secara statistik menggunakan software juga menunjukkan bahwa perolehan nilai p-value $=0,858$ yang lebih besar dari taraf signifikansi 0,05 dan parameter dispersinya sebesar 0,68 lebih besar dari 0 serta rasio dispersi 1,170 lebih besar dari 1.

\section{Model Regresi Poisson Tergeneralisasi}

Masalah overdispersi dapat disebabkan oleh beberapa hal, misalnya adanya pengamatan yang hilang dan adanya data pencilan. GPR atau regresi poison tergeneralisasi merupakan salah satu alternatif untuk memodelkan data dengan overdispersi. Model regersi poisson tergeneralisasi dapat dinyatakan sebagai berikut:

$\ln (\theta)=X_{i}^{T} \beta=\beta_{0}+\beta_{1} x_{i 1}+\beta_{2} x_{i 2}+\cdots+$ $\beta_{j} x_{i j}$

$\theta=\exp \left(X_{i}^{T} \beta\right)=\exp \left(\beta_{0}+\sum_{j=1}^{p} \beta_{j} x_{i j}\right)$ dengan $x_{i j}$ : peubah penjelas ke-j amatan ke$i, \beta_{0}$ : konstanta, $\beta_{j}$ : koefisien regresi peubah penjelas ke-j, $N$ : banyaknya amatan, $p$ : banyaknya peubah penjelas.

Fungsi peluang poisson tergeneralisasi dituliskan sebagai berikut (McCullagh \& Nelder, 1998; Famoye et al., 2004).

$f\left(y_{i}, \theta_{i}, \phi\right)=$

$\left(\frac{\theta_{i}}{1+\phi \theta_{i}}\right)^{y_{i}} \frac{\left(1+\phi y_{i}\right)^{y_{i}-1}}{y_{i} !} \exp \left(-\frac{\theta_{i}\left(1+\phi y_{i}\right)}{\left(1+\phi \theta_{i}\right)}\right)$ 
dengan rataan dan ragam masing-masing adalah $\theta_{i}$ dan $\theta_{i}\left(1+\phi \theta_{i}\right)^{2}$. Parameter $\theta$ merupakan parameter natural dan $\phi$ sebagai parameter dispersi. Fungsi peluang pada persamaan (9) dapat ditulis dalam bentuk berikut

$f(y, \theta, \phi)=\exp \left\{y\left(\ln \left(\frac{\theta}{1+\phi \theta}\right)-\frac{\phi \theta}{(1+\phi \theta)}\right)-\right.$ $\left.\frac{\theta}{(1+\phi \theta)}+(y-1) \ln (1+\phi y)-\ln y !\right\}$

Persamaan (10), menunjukkan bahwa distribusi GP termasuk dalam distribusi keluarga eksponensial yang berbentuk seperti pada persamaan (2), dengan $a(y)=$ $y ; \quad b(\theta, \phi)=\ln \left(\frac{\theta}{1+\phi \theta}\right)-\frac{\phi \theta}{(1+\phi \theta)}$ $c(\theta, \phi)=-\frac{\theta}{(1+\phi \theta)} ;$ dan

$$
d(y, \phi)=(y-1) \ln (1+\phi y)-\ln y !
$$

Model regresi poisson tergeneralisasi digunakan karena adanya overdispersi pada model regresi Poisson. Model regresi poisson tergeneralisasi dibangun dengan menggunakan kombinasi dari variabel prediktor yang ada dan kebaikan modelnya diukur dari nilai AIC.

Tabel 4, merupakan kombinasi variabel prediktor yang memiliki nilai AIC terkecil dari 31 kombinasi yang dapat dibentuk. Pada regresi dengan satu variabel bebas, dari 5 kemungkinan model yang paling baik, yaitu jumlah bayi berat lahir rendah $\left(\mathrm{X}_{2}\right)$. Model terbaik dengan 2 variabel bebas dipilih dari 10 kombinasi model dimana model terbaiknnya yaitu $\mathrm{X}_{2}$ dan $\mathrm{X}_{5}$. Model terbaik dengan 3 variabel bebas dipilih dari 10 kombinasi model dimana model terbaiknya yaitu $\mathrm{X}_{2}, \mathrm{X}_{3}$ dan $X_{5}$. Model terbaik dengan 4 variabel bebas dipilih dari 5 kombinasi model dimana model terbaiknya yaitu $\mathrm{X}_{2}, \mathrm{X}_{3}, \mathrm{X} 4$ dan $\mathrm{X}_{5}$. Sedangkan model dengan 5 variabel bebas adalah model lengkap (Tabek 4).

Tabel 4. Kombinasi Nilai AIC

\begin{tabular}{cc}
\hline Model & AIC \\
\hline $\exp \left(\beta_{0}+\beta_{2} X_{2}\right)$ & 54,645 \\
$\exp \left(\beta_{0}+\beta_{2} X_{2}+\beta_{5} X_{5}\right)$ & 53,932 \\
$\exp \left(\beta_{0}+\beta_{2} X_{2}+\beta_{3} X_{3}+\beta_{5} X_{5}\right)$ & 54,181 \\
$\exp \left(\beta_{0}+\beta_{2} X_{2}+\beta_{3} X_{3}+\beta_{4} X_{4}\right.$ & 55,712 \\
& $\left.+\beta_{5} X_{5}\right)$ \\
$\exp \left(\beta_{0}+\beta_{1} X_{1}+\beta_{2} X_{2}+\beta_{3} X_{3}\right.$ & 57,703 \\
& $\left.+\beta_{4} X_{4}+\beta_{5} X_{5}\right)$ \\
\hline
\end{tabular}

Berdasarkan Tabel 4, terlihat bahwa model terbaiknya adalah kombinasi antara $\mathrm{X}_{2}$ dan $\mathrm{X}_{5}$ karena memiliki nilai AIC terkecil.
Hasil estimasi parameter yang disajikan pada Tabel 5 menunjukkan bahwa pada taraf nyata $5 \%$, peubah $X_{2}$ secara signifikan berpengaruh terhadap respon karena nilai-p kurang dari 0,05 . Berdasarkan tabel tersebut, model regresi poisson tergeneralisasi dengan AIC terbaik dapat dituliskan sebagai:

$$
\widehat{\boldsymbol{\theta}}=\exp \left(0,892+0,019 X_{2}-0,035 X_{5}\right)
$$

Tabel 5. Estimasi Nilai $\beta$ pada Model Regresi Poisson Tergeneralisasi

\begin{tabular}{ccccl}
\hline $\begin{array}{c}\text { Para- } \\
\text { meter }\end{array}$ & $\begin{array}{c}\text { Esti- } \\
\text { masi }\end{array}$ & $\begin{array}{c}\text { Galat } \\
\text { Baku }\end{array}$ & Wald & Nilai-p \\
\hline Intersep & 0,892 & 1,313 & & 0,837 \\
$\beta_{2}$ & 0,019 & 0,006 & 8,030 & $0,004 * *$ \\
$\beta_{5}$ & $-0,035$ & 0,021 & 2,714 & 0,099 \\
\hline
\end{tabular}

Persamaan (8), menunjukkan bahwa setiap penambahan satu kasus bayi dengan BBLR $\left(X_{2}\right)$ akan menaikkan rataan jumlah kasus gizi buruk sebesar $\exp (0,019)=1,019$. Hal ini berarti, pertambahan satu satuan kasus BBLR di sebuah kota/kabupaten akan diikuti oleh kenaikan nilai harapan jumlah penderita gizi buruk sebesar 1,019 kali dibanding kota/kabupaten lain dengan asumsi peubah lain dianggap tetap. Selain itu, setiap penambahan $1 \%$ bayi penerima ASI eksklusif $\left(X_{5}\right)$ akan mengurangi rataan jumlah kasus gizi buruk sebesar $\exp (0,035)=0,965$.

Hasil uji wald untuk model pada persamaan (8) dengan menggunakan rumus pada persamaan (4), menunjukkan bahwa nilai wald dari variabel $X_{2}$ adalah 8,030 yang lebih besar dari $X_{(1 ; 0,05)}=3,841$. Hal ini berarti berat bayi lahir rendah secara signifikan mempengaruhi rataan banyaknya kasus gizi buruk. Sebaliknya, $X_{5}$ yaitu persentase bayi yang diberi ASI eksklusif tidak signifikan karena memiliki nilai wald 2,714 yang lebih kecil dari nilai tabel.

Temuan ini mengisyaratkan bahwa kasus BBLR menjadi ancaman utama dalam upaya menekan kasus gizi buruk di Propinsi Sulut. Hal ini sejalan dengan penelitian yang dilakukan oleh Darwis et al. (2017), yang menyimpulkan bahwa untuk kasus di Kota Kendari, bayi dengan BBLR memiliki resiko 7 kali lebih besar mengalami gizi buruk dibandingkan dengan balita yang memiliki berat badan lahir normal. 


\section{KESIMPULAN}

Model regresi poisson tergeneralisasi untuk jumlah kasus gizi buruk, yaitu: $\widehat{\boldsymbol{Y}}=$ $\exp \left(0,892+0,019 X_{2}\right)$. Faktor yang mempengaruhi rataan jumlah gizi buruk di Sulawesi Utara adalah jumlah bayi dengan berat badan lahir rendah (BBLR). Jika kasus BBLR di sebuah kota/kabupaten bertambah satu satuan maka nilai harapan jumlah penderita gizi buruk akan meningkat sebesar 1,019 kali dibanding kota/kabupaten lain dengan asumsi peubah lain dianggap tetap.

\section{DAFTAR PUSTAKA}

Agresti, A. 2006. An Introduction to Categorical Data Analysis: $2^{\text {nd }}$ edition. In An Introduction to Categorical Data Analysis: Second Edition. https://doi.org/10.1002/0470114754.

BAPPENAS. 2006. Rencana Aksi Nasional Pangan dan Gizi 2006-2010.

BPS Provinsi Sulawesi Utara. 2019. Provinsi Sulawesi Utara Dalam Angka 2019.

Darwis, R.E., R. Majid \& Ainurafiq. 2017. Analisis Determinan yang Berhubungan Dengan Kejadian Gizi Kurang Pada Balita Usia 12-59 Bulan di Wilayah Kerja Puskesmas Benu-Benua Kota Kendari Tahun 2017. Jurnal Ilmiah Mahasiswa Kesehatan Masyarakat, 2(6): 1-14.

Dobson, A.J. \& A.G. Barnett. 2018. An Introduction to Generalized Linear Models $4^{\text {th }}$ edition. CCRC Press, Taylor \& Francis Group.

Famoye, F., J.T. Wulu \& K. Singh. 2004. On the Generalized Poisson Regression Model with an Application to Accident Data. Journal of Data Science, 2(3): 287-295. https://doi.org/10.6339/JDS.2004.02(3) .167

Hocking, R.R. 1996. Methods and Applications of Linear Models, $2^{\text {nd }}$ edition. John Wiley and Sons Inc, New York.
Hosang, K.H., A. Umboh \& H. Lestari. 2017. Hubungan Pemberian Makanan Tambahan Terhadap Perubahan Status Gizi Anak Balita Gizi Kurang di Kota Manado. Jurnal e-Clinic (eCl), 5(1): 15. https://doi.org/10.35790/ecl.5.1.2017 .14760 .

Kumayas, V., Nancy S.H. Malonda \& Maureen I. Punuh. 2019. Hubungan antara status imunisasi dan penyakit infeksi dengan status gizi pada balita usia 24-59 bulan di Desa Tateli Dua Kecamatan Mandolang, Kabupaten Minahasa. Jurnal KESMAS, 8(6): 299305.

McCullagh, P. \& J.A. Nelder. 1989. Generalized Linier Models, $2^{\text {nd }}$ edition. Chapman and Hall, London.

Walpole, R. E. 1995. Pengantar Metode Statistika. PT Gramedia Pustaka Utama, Jakarta. 